TEME, г. XLIV, бр. 2, април - јун 2020, стр. 533-548

Прегледни рад

https://doi.org/10.22190/TEME180918038P

Примљено: 18. 9. 2018.

UDK 640.4

Ревидирана верзија: 20. 1. 2020.

Одобрено за штампу: 15. 4. 2020.

\title{
MODIFIED MULTI-CRITERIA METHODS FOR IMPROVING SERVICE QUALITY
}

\author{
Jelena Petrović \\ University of Niš, Faculty of Science and Mathematics, Niš, Serbia \\ jelena25@pmf.ni.ac.rs
}

\begin{abstract}
The development of the new and the modification of existing methods for improving the measurement of service quality is a basic prerequisite for the successful business of hotels, as well as their survival on the global market. The main objective of this paper is the modification of the ENTROPY and VIKOR methods, for the purpose of simplifying the measurement of service quality. In order to take account of the different guest expectations in hotels in cities, mountains and spas, the modification of the ENTROPY method has been performed with the aim of calculating the weight coefficients for each criterion within each alternative, i.e. calculating the weight coefficients for each dimension of service quality, separately for hotels in cities, hotels in mountains, and hotels in spas. Based on weight coefficients and the modified VIKOR method, the ranking of hotels has been carried out with regard to service quality. The modified multicriteria methods provide adequate information to hotel managers on the extent to which the services provided in their hotel match the expectations of their guests, as well as on the service quality offered by the competitors.
\end{abstract}

Key words: $\quad$ hotel, expectation, perception, service quality, modified method.

\section{МОДИФИКОВАЊЕ ВИШЕКРИТЕРИЈУМСКИХ МЕТОДА У ЦИЉУ УНАПРЕЪЕЊА КВАЛИТЕТА УСЛУГА}

\section{Апстракт}

Развој нових метода и модификовање постојећих у циљу унапређења мерења квалитета услуга је основни предуслов за успешно пословање хотела, као и за њихов опстанак на глобалном тржишту. Главни циљ рада је модификација ENTROPY и VIKOR методе ради поједностављења мерења квалитета услуга. Имајући у виду различита очекивања гостију у зависности од тога да ли посећују хотеле у градовима, на планинама или бањама, извршена је модификација ENTROPY методе са циљем израчунавања тежинских коефицијената за сваки критеријум сваке алтернативе, тј. одређивање тежинских коефицијената за сваку димензију квалитета услуга, појединачно за хотеле у градовима, хотеле на планинама и хотеле у бањама. На основу тежинских коефицијената и модификоване VIKOR методе, рангирање хотела извршено је полазећи од квалитета услуга. Модификоване вишекритеријумске 
методе обезбеђују адекватне информације менаџерима хотела у којој мери пружене услуге одговарају очекивањима њихових гостију, као и информације о квалитету услуга које нуде њихови конкуренти.

Кључне речи: хотел, очекивање, перцепција, квалитет услуга, модификована метода.

\section{INTRODUCTION}

Service quality is a concept that has aroused considerable interest and debate in the research literature because of the difficulties in both defining it and measuring it with no overall consensus emerging on either (Wisniewski, 2001). Service quality is more difficult to be evaluated than commodity quality, but it plays an especially important role in firms to improve customer satisfaction and customer loyalty (Liua et al., 2015).

Service quality influences a traveler's decision to return to the hotel (Chen, 2013). It has positive effects on the hotels' economic performance (Skalpe \& Sandvik, 2002). Executives often understand the need to maintain good service quality, but find it difficult to do so, due to the absence of a universal benchmark that service performance can be compared to because of the varying levels of customer expectations (Wattanakamolchai, Signal, \& Murrman, 2014). Understanding that the different segments have different aspects is a key phase in delivering high quality services. Numerous methods are used to gain insight into guest expectations regarding the quality of hotel services. But, the SERVQUAL model is one of the most used models for identifying the possible causes for the gap between expected quality and perceived quality. The SERVQUAL model was first developed in 1985 and then further modified by Parasuraman, Zeithaml and Berry (1988; 1994; 1990; 1991; 1993).

When studying researches from the past, it becomes apparent that the results of the SERVQUAL model are calculated with statistical methods. Today, multi-criteria methods have an increasingly important application instead of the statistical methods in measuring services quality (Mukherjee \& Nath, 2005; Buyukozkan, Ruan, \& Feyzioglu, 2007; Shieh, Wu, \& Huang, 2010; Tsai, Chang, \& Lin, 2010). However, their use for measuring quality services in tourism is rare.

Liou, Tsai, Lin and Tzeng (2011) have taken into account different aspects of the importance of individual determinants of service quality in measuring airline services quality. However, they only performed the modification of the VIKOR method which allows for the application of weight coefficients for each criterion within each alternative (airline), on the basis of the importance of certain dimensions of airline service quality for passengers, without the development of a new or modification of the method that would allow an objective determination of the values of these weight coefficients. 
Having in mind the fact that criteria weights can significantly influence the result of the decision-making process, it is clear that special attention must be paid to the objectivity of criteria weights, which is, unfortunately, not always present when solving theoretical and practical problems. In order to take account of different guest expectations, it is necessary to modify the ENTROPY method, to allow the calculation of the weight coefficients for each criterion within each alternative. In order to check the stability of the alternatives on the ranking lists, we are going to employ two methods of the weight coefficient value - the traditional and the modified ENTROPY method. In the paper, starting from the results of the adapted SERVQUAL questionnaire for the measurement of hotel service quality, we will use: 1) the traditional VIKOR and ENTROPY method, 2) the modified VIKOR and ENTROPY method, 3) the statistical method.

\section{THEORETICAL BACKGROUND}

\section{The Multi-Criteria Methods}

The methods of the multi-criteria analysis that have significant application in social areas are: the ELECTRE method, PROMETHEE, the analytic hierarchy process, and TOPSIS and VIKOR (Multi-Criteria Compromise ranking). The VIKOR method, which will be given special attention in this paper, has been developed on the basis of the elements from compromise programming. The method starts from the "limit" forms of $L_{p}-$ metrics (Opricovic, 1986). It is necessary to find a solution that is closest to the ideal. It is especially suitable for application in situations in which quantitative criteria prevail.

The VIKOR method has significant application in decision-making processes in the field of service quality, marketing, insurance, banking, and so on (Wu, Tzeng, \& Chen, 2009; Fu, Chu, Chao, Lee, \& Liao, 2010; Shaverdi, Akbari, \& Tafti, 2011; Bazzazi, Osanloo, \& Karimi, 2011; Yucenur \& Demirel, 2012; Ramezaniyan, Kazemi, Jafari, \& Elahi, 2012; Mohaghar, Faithi, Zarchi, \& Omidian, 2012; Kumar, Singh, \& Dureja, 2012; Chen, 2013; Vinodh, Nagaraj, \& Girubha, 2014; Buyukozkan \& Gorener, 2015). Wang and Pang (2011) have used the VIKOR method as the main device in ranking the service quality of three online auctions. Liou et al. (2011) applied the modified VIKOR method to establish the gaps in priorities between alternatives and aspired-levels. The fuzzy VIKOR is applied to the analysis of customer satisfaction with Turkish banks in within Borsa Istanbul (Hasan \& Umit, 2013). When applying the VIKOR methods in measuring service quality, the above-mentioned authors determined the weight coefficients by using some objective methods which allow the calculation of the weight criteria for each criterion within all alternatives. 


\section{RESEARCH METHODOLOGY AND HYPOTHESIS}

This work relies on the following methods: the traditional VIKOR and ENTROPY methods, the modified VIKOR and ENTROPY methods and the statistical method. The research information base has included the results of a survey. The hypothesis to be tested in this study is as follows:

H1: The traditional ENTROPY and the traditional VIKOR methods result in the same ranking of the observed alternatives, as well as the statistical methods.

H2: The modified ENTROPY and the modified VIKOR methods result in the different ranking of the observed alternatives compared to the statistical methods.

\section{The Modified ENTROPY Method}

The main difference between the traditional and the modified ENTROPY method is the way of determining the weight coefficients values. The application of the traditional ENTROPY method allows the calculation of the weight coefficient for each criterion within all alternatives and does not respect the different guest expectations. Modification of ENTROPY method allows for the appreciation of different guest expectations that are in cities, the mountains, and spas. This method allows for the calculation of the weight coefficients for each criterion within each alternative.

Within the ENTROPY method, determining the weight criterions were implemented through the three steps (Shannon, 1948). In the first step, the normalization of the criterion value was performed by the expression:

$$
r_{i j}=\frac{a_{i j}}{\sum_{i=1}^{n} a_{i j}}
$$

In this way, the initial matrix is converted into the normalization decision matrix:

$$
\begin{aligned}
& \begin{array}{lllll}
c_{1} & \cdots & c_{j} & \cdots & c_{n}
\end{array}
\end{aligned}
$$

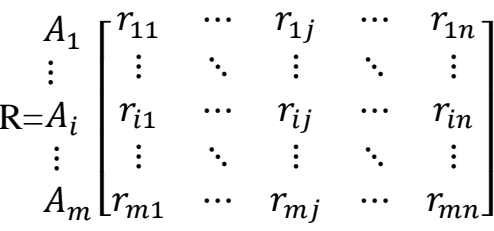

The amount of information contained in the normalization decision matrix can be measured as entropy value $e_{j}$ :

$$
e_{j}=-k \sum_{i=1}^{n} r_{i j} \ln r_{i j}
$$


Instead of the traditional determination of the entropy value $e_{j}$, we will calculate for every alternative $e_{i j}$ by the next equation:

$$
e_{i j}=-\mathrm{k} r_{i j} \ln r_{i j}
$$
$[0,1]$.

Constant $k=1 /$ lnn transforms all the entropy values into interval

In the second step, within the traditional ENTROPY method, the degree of divergence in relation to the average amount of information contained in each criterion is determined by the following equation:

$$
d_{j}=1-e_{j}
$$

$d_{j}$ represents the contrast intensity of criterion $C_{j}$.

Within the modified ENTROPY method, we determined:

$$
d_{i j}=1-e_{i j}
$$

In the third step, within the traditional method, the objective criteria weights are obtained with the normalization of the value $d_{j}$ :

$$
w_{j}=\frac{d_{j}}{\sum_{j=1}^{m} d_{j}}
$$

Within the modified method, the objective criteria weights are obtained with the normalization of the value $d_{j}$ :

$$
w_{i j}=\frac{d_{i j}}{\sum_{i=1}^{n} d_{i j}}
$$

\section{The Modified VIKOR Method}

The VIKOR method represents a method for multi-criterion optimization, which makes a decision regarding the choice of the best constructive based on the given final set of alternatives. Through the use of this method, a compromise ranking list, i.e. a compromise solution, is determined with the help of weight coefficients, by means of which different weight coefficients are determined for each criterion, especially those that relate to all alternatives.

Within the first scenario, starting from the guest expectations and the ENTROPY method, we determined the criteria weight values for each criterion of all alternatives. The calculated weight coefficients are applied within the traditional VIKOR method. Within the second scenario, the modification of the VIKOR method is performed on the basis of the calculation of the weight coefficient for each criterion of each alternative, thus forming the initial decision matrix. The steps for calculating the traditional and modified VIKOR methods are as follows: 
The decision matrix that represents our starting point is:

$$
\begin{aligned}
& \begin{array}{lllll}
c_{1} & \cdots & c_{j} & \cdots & c_{n}
\end{array}
\end{aligned}
$$

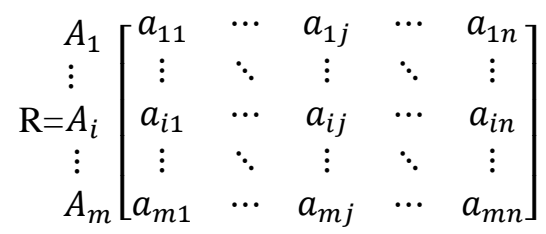

Step 1 - Determining the highest and the lowest value of the given criterion. Starting from the guest perceptions, for each criterion of each alternative we determine: "the highest," as the quality level of the hotel service that is strived for, and "the lowest," as the lowest perception of the hotel service quality for each criterion. In addition to this, "the highest" represents the desired level of the hotel service quality, whereas "the lowest" represents the lowest perception of the hotel service quality for each criterion of each alternative.

With the purpose of easier review and calculation of $S_{i}$ and $R_{i}$, the values $d_{i j}$ are introduced and defined as:

$$
d_{i j}=\frac{\left|f_{j}^{*}-f_{i j}\right|}{\left|f_{j}^{*}-f_{j}^{-}\right|}
$$

Step 2 - Within the traditional VIKOR method, the values $S_{i}$ and $R_{i}$ are determined:

$$
\begin{gathered}
S_{i}=\sum_{j=1}^{n} w_{j} \frac{f_{j}^{*}-f_{i j}}{f_{j}^{*}-f_{j}^{-}}=\sum_{j=1}^{n} w_{j} d_{i j} ; i=1,2, \ldots \ldots, m \\
R_{i}=\max _{j} w_{j} d_{i j} ; i=1,2, \ldots \ldots, m
\end{gathered}
$$

Within the modified VIKOR method, the values $S_{i}^{m}$ and $R_{i}^{\mathrm{m}}$ are determined:

$$
\begin{gathered}
S_{i}^{m}=\sum_{j=1}^{n} w_{j}^{i} \frac{f_{j}^{*}-f_{i j}}{f_{j}^{*}-f_{j}^{-}}=\sum_{j=1}^{n_{i}} w_{j}^{i} d_{i j} \quad i=1,2, \ldots \ldots, m \quad \sum_{j=1}^{n_{i}} w_{j}^{i}=1 \\
R_{i}^{\mathrm{m}}=\max _{j}\left\{w_{j}^{i} d_{i j} \mid j=1,2, \ldots, n_{i}\right\} \quad i=1,2, \ldots \ldots, m
\end{gathered}
$$

In the second step, the modification of the VIKOR method is carried out. Within the modified VIKOR method, the pessimistic $\left(\mathrm{S}_{\mathrm{i}}{ }^{\mathrm{m}}\right)$ and the expected $\left(\mathrm{R}_{\mathrm{i}}^{\mathrm{m}}\right)$ solutions are calculated, based on the weight coefficients, obtained using a modified ENTROPY method, i.e. based on weight criteria for each criterion within each alternative.

Step 3 - calculating $Q_{i}$. In the traditional VIKOR method, $S^{*}=$ $\min _{i} S_{i}, S^{-}=\max _{i} S_{i}$, whereas $R^{*}=\min _{i} R_{i}$ and $R^{-}=\max _{i} R_{i}$. In this way, we could obtain results which show a relative relation of these alternatives when calculating $Q_{i}$. However, the gap equal to zero is marked as 
the best level, whereas the gap equal to one is marked as the worst one, so $Q_{i}$ shows an absolute relation among these alternatives. The value $Q S_{i}$ represents the measure of deviation, by means of which a demand for the maximum gap that should be reduced is calculated, whereas $Q R_{i}$ represents the measure of deviation, by means of which a demand for minimizing the maximum distance of some alternative from the "ideal" one is shown.

Determination of the values $Q_{i}, i=1,2, \ldots m$

$$
Q_{i}=\frac{i\left(S_{i}-S^{*}\right)}{\left(S^{-}-S^{*}\right)}+(1-i)\left(R_{i}-R^{*}\right) /\left(R^{-}-R^{*}\right), \text { where is } 0 \leq v \geq 1
$$

When performing a multi-criteria ranking based on the VIKOR method, the alternative $A_{i}$ is considered to be better than $A_{k}$ (according to all criteria) if $Q_{i}<Q_{k}$. This compromise solution is stable within a decision making process, which could be the strategy of maximum group utility (when $v>0.5$ is needed), or "by consensus" $v \approx 0.5$, or "with veto" $(v<0.5)$. Here, $v$ is the weight of decision making strategy of maximum group utility (Opricovic \& Tzeng, 2007). In this paper, the ranking of alternatives is made on the basis of the following values $v$, namely: $0,0.5$, and 1 .

\section{THE DATA FOR THE EMPIRICAL CASE}

\section{Questionnaire Design}

In order to improve the quality of hotel services, it is necessary to determine which hotel or group of hotels offer the highest level of quality service. To measure service quality, the most commonly used is the SERVQUAL method. The SERVQUAL methodology requires the formulation of 22 pairs of questions, where the examinees are first asked one of the series of 22 questions before the use of the service, by means of which expectations are measured, and then, after the use of the service, they are asked another series of 22 categorized questions, in order to measure experience, i.e. the perception (attitude) of users regarding the provided service.

Based on the analysis of SERVQUAL questionnaire, as well as the above-mentioned questionnaires, the questionnaire including 30 questions was formed. A survey on the sample of 458 hotel guests was conducted, who rated the issues with a score from 1 to 5 , from the standpoint of the significance of the issues for the quality of hotel services. Starting from the significance of issues, the new questionnaire was formed, containing 24 questions. The first 12 questions from the questionnaire related to "tangible" elements, and other questions covered four dimensions (reliability, responsibility, assurance, and empathy), related to intangible elements. In addition to 9 new questions, the survey included 15 questions from the original SERVQUAL questionnaire, which were adapted to measure the quality of hotel services. 
The questionnaire consists of two parts. The first part refers to the guest expectations, and the second to their perception, i.e. the quality of perceived services. The first question on the scale of expectations, "the hotel should have good location and accessibility", on the scale of perception read "the hotel has good location and accessibility". The second question on the scale of expectations, "the hotel exterior should be visually appealing to guests", on the scale of perception read "the hotel exterior is visually appealing to guests". All other questions on the scale expectations are formulated in this manner.

To measure the guest expectations, the five-point Likert scale was used, where one end of the scale referred to the response "totally unimportant", and the other end to "very important". To measure guest perceptions, the five-point Likert scale was also used, where one end of the scale referred to the response "strongly disagree", and the other end of the scale to "strongly agree".

\section{Results of the Survey}

The survey was conducted in hotels that are located in the mountains (Kopaonik, Zlatibor, Tara, and Stara Planina, in cities (Belgrade, Novi Sad, Niš, Kragujevac), and in Serbian spas (Vrnjačka banja, Sokobanja, Prolom banja, and Ribarska banja) where 6558 hotel guests were surveyed. After the elimination of questionnaires with incomplete answers, we got a useful sample of 6652 questionnaires, where 2085 questionnaires were conducted in hotels that are located in the mountain centers, 2614 in hotels that are located in cities, and 1953 in hotels found in Serbian spas.

Table 1. Guests profiles

\begin{tabular}{lcc}
\hline Attributes/distribution & Sample number & Frequency $(\%)$ \\
\hline Gender & & \\
Male & 2636 & 39.62 \\
Female & 4016 & 60.38 \\
Age & & \\
18 or younger & 237 & 3.57 \\
19-29 & 2584 & 38.85 \\
30-39 & 1482 & 22.28 \\
40-49 & 692 & 10.4 \\
50-59 & 883 & 13.28 \\
60 or older & 773 & 11.62 \\
Education & & \\
Primary & 86 & 1.3 \\
Secondary & 2508 & 37.7 \\
College & 1106 & 16.62 \\
Faculty & 2872 & 43.17 \\
Doctorate & 82 & 1.23 \\
\hline$\quad$ Source: Compiled & & \\
\hline
\end{tabular}

Source: Compiled by author based on survey (SPSS 19) 


\section{RESULTS OF THE EMPIRICAL ANALYSIS}

Table 2 shows average values of the hotel guest expectations and perceptions pertaining to hotels located in cities, mountain centers, and spas in Serbia. With regard to the determinants of the services quality, hotel guests have different expectations, depending on whether they are visiting hotels in mountain resorts, cities, or spa resorts. The same situation is with their perceptions. The above affects the formation of different service quality gaps in hotels, i.e. different levels of services quality provided by hotels in mountain resorts, cities, and spas.

Table 2. Guest expectation and perception

\begin{tabular}{|c|c|c|c|c|c|c|}
\hline \multirow{2}{*}{$\begin{array}{l}\text { Dimension and } \\
\text { determination of } \\
\text { quality }\end{array}$} & \multicolumn{2}{|c|}{$\begin{array}{l}\text { Hotels in mountain } \\
\text { resorts }\left(A_{1}\right)\end{array}$} & \multicolumn{2}{|c|}{$\begin{array}{l}\text { Hotels in towns } \\
\qquad\left(\mathrm{A}_{2}\right)\end{array}$} & \multicolumn{2}{|c|}{$\begin{array}{l}\text { Hotels in spa resorts } \\
\left(\mathrm{A}_{3}\right)\end{array}$} \\
\hline & Expectation & Perception & Expectation & Perception & Expectation & Perception \\
\hline \multicolumn{7}{|l|}{ Tangibility } \\
\hline Hotel location & 4.62 & 4.53 & 4.53 & 4.35 & 4.59 & 4.43 \\
\hline Hotel exterior & 4.38 & 4.53 & 4.52 & 4.42 & 4.48 & 3.99 \\
\hline $\begin{array}{l}\text { Cleaning garden } \\
\text { area }\end{array}$ & 3.94 & 4.00 & 3.95 & 3.02 & 3.86 & 3.65 \\
\hline Hotel interior & 4.50 & 4.43 & 4.60 & 4.14 & 4.56 & 4.10 \\
\hline $\begin{array}{l}\text { Assortment and } \\
\text { quality of drinks }\end{array}$ & 3.95 & 4.10 & 4.11 & 2.98 & 4.01 & 3.76 \\
\hline Quality of food & 4.86 & 4.42 & 4.85 & 4.16 & 4.80 & 3.98 \\
\hline $\begin{array}{l}\text { Assortment of } \\
\text { food }\end{array}$ & 4.64 & 4.43 & 4.65 & 4.18 & 4.61 & 3.95 \\
\hline $\begin{array}{l}\text { Restaurant - } \\
\text { cleaning and } \\
\text { maintenance }\end{array}$ & 4.85 & 4.44 & 4.82 & 4.26 & 4.85 & 4.09 \\
\hline $\begin{array}{l}\text { Rooms - } \\
\text { cleaning and } \\
\text { maintenance }\end{array}$ & 4.91 & 4.50 & 4.87 & 4.32 & 4.88 & 4.13 \\
\hline $\begin{array}{l}\text { Appearance of } \\
\text { employees and } \\
\text { managers }\end{array}$ & 4.64 & 4.49 & 4.68 & 4.32 & 4.65 & 4.18 \\
\hline $\begin{array}{l}\text { Entertainment } \\
\text { and shows }\end{array}$ & 3.99 & 3.86 & 4.05 & 3.58 & 3.88 & 3.58 \\
\hline $\begin{array}{l}\text { Recreation and } \\
\text { wellness } \\
\text { facilities }\end{array}$ & 4.06 & 4.15 & 4.17 & 3.52 & 4.11 & 3.93 \\
\hline \multicolumn{7}{|l|}{ Reliability } \\
\hline $\begin{array}{l}\text { Providing } \\
\text { services within } \\
\text { the promised } \\
\text { time }\end{array}$ & 4.54 & 4.14 & 4.6 & 4.05 & 4.66 & 3.93 \\
\hline $\begin{array}{l}\text { Providing } \\
\text { services with no } \\
\text { errors }\end{array}$ & 4.48 & 3.99 & 4.47 & 3.86 & 4.56 & 3.90 \\
\hline $\begin{array}{l}\text { Providing pre- } \\
\text { agreed services }\end{array}$ & 4.63 & 4.20 & 4.51 & 4.14 & 4.60 & 4.13 \\
\hline
\end{tabular}




\begin{tabular}{|c|c|c|c|c|c|c|}
\hline \multirow{2}{*}{$\begin{array}{l}\text { Dimension and } \\
\text { determination } \\
\text { of quality }\end{array}$} & \multicolumn{2}{|c|}{$\begin{array}{l}\text { Hotels in mountain } \\
\text { resorts }\left(A_{1}\right)\end{array}$} & \multicolumn{2}{|c|}{$\begin{array}{c}\text { Hotels in towns } \\
\left(\mathrm{A}_{2}\right)\end{array}$} & \multicolumn{2}{|c|}{$\begin{array}{l}\text { Hotels in spa resorts } \\
\qquad\left(\mathrm{A}_{3}\right)\end{array}$} \\
\hline & Expectation & Perception & Expectation & Perception & Expectation & Perception \\
\hline \multicolumn{7}{|l|}{ Responsibility } \\
\hline $\begin{array}{l}\text { The willingness } \\
\text { of employees to } \\
\text { always assist } \\
\text { guests }\end{array}$ & 4.61 & 4.19 & 4.69 & 4.05 & 4.64 & 3.90 \\
\hline $\begin{array}{l}\text { The willingness } \\
\text { of employees to } \\
\text { always answer } \\
\text { guests' } \\
\text { questions }\end{array}$ & 4.59 & 4.26 & 4.55 & 4.03 & 4.60 & 3.89 \\
\hline $\begin{array}{l}\text { Timeliness of } \\
\text { employees }\end{array}$ & 4.53 & 4.14 & 4.50 & 4.03 & 4.53 & 3.94 \\
\hline \multicolumn{7}{|l|}{ Assurance } \\
\hline $\begin{array}{l}\text { Friendliness of } \\
\text { employees }\end{array}$ & 4.71 & 4.35 & 4.80 & 4.36 & 4.71 & 4.23 \\
\hline $\begin{array}{l}\text { Professionalism } \\
\text { of employees }\end{array}$ & 4.57 & 4.27 & 4.65 & 4.11 & 4.54 & 4.17 \\
\hline $\begin{array}{l}\text { The feeling of } \\
\text { security } \\
\text { (personal and } \\
\text { material) of } \\
\text { guests }\end{array}$ & 4.79 & 4.74 & 4.81 & 4.04 & 4.84 & 4.54 \\
\hline \multicolumn{7}{|l|}{ Empathy } \\
\hline $\begin{array}{l}\text { Providing } \\
\text { individual } \\
\text { attention to each } \\
\text { guest }\end{array}$ & 3.86 & 3.91 & 3.97 & 3.83 & 4.03 & 3.50 \\
\hline $\begin{array}{l}\text { Honest and } \\
\text { empathic } \\
\text { treatment of } \\
\text { guests }\end{array}$ & 3.91 & 3.87 & 3.95 & 3.83 & 3.95 & 3.73 \\
\hline $\begin{array}{l}\text { Understanding } \\
\text { of specific } \\
\text { guests`needs }\end{array}$ & 4.03 & 4.03 & 4.13 & 3.86 & 4.15 & 3.76 \\
\hline
\end{tabular}

\section{RESULTS AND DISCUSSIONS}

Calculation of the Weight Coefficients by the Traditional ENTROPY method and Determination of the Traditional Matrix (the VIKOR Method)

Starting from guest perceptions and the formula 5) within the VIKOR method, we formed the following matrix:

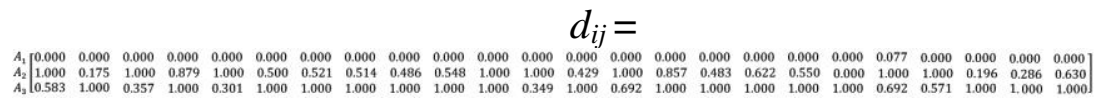

Starting from guest perceptions and the formulas (1), (2), (3) and (4) within the traditional ENTROPY method, we obtain the criteria weights $w_{j}$. According to the traditional VIKOR method, we formed the traditional matrix: 


$$
d_{i j} w_{j}=
$$

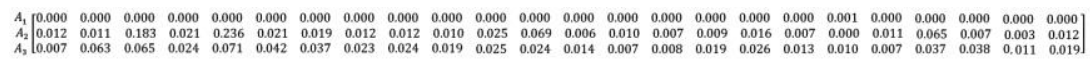

\section{Calculation of the Weight Coefficients by the Modified ENTROPY Method and Determination of the Modified Matrix (the Modified VIKOR Method)}

Starting from guest expectations and the formulas (1), (2a), (3a) and (4) within the modified ENTROPY method, we obtain the criteria weights $w_{i j}$. According to the modified ENTROPY method which encompasses the special weight coefficient for each criterion of each alternative and the modified VIKOR method, we formed the modified matrix:

$$
d_{i j} w_{i j}=
$$

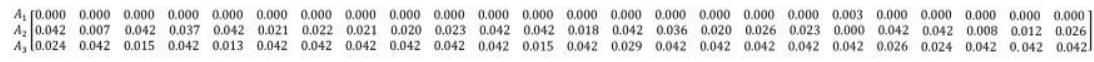

Determination of the values $S_{i}, R_{i}, Q_{i}(v=0), Q_{i}(v=0.5)$ and $Q_{i}(v=1)$

Table 3. The ranking of alternatives by using the traditional VIKOR and the modified VIKOR method

\begin{tabular}{lcccccc}
\hline Method & & $S_{i}$ & $R_{i}$ & $\mathrm{Q}_{i}(v=0)$ & $\mathrm{Q}_{i}(v=0.5)$ & $\mathrm{Q}_{i}(v=1)$ \\
\hline \multirow{2}{*}{ The traditional } & $\mathrm{A}_{1}$ & 0.0000 & 0.0000 & 0.0000 & 0.0000 & 0.0000 \\
VIKOR method & $\mathrm{A}_{2}$ & 1.0000 & 1.0000 & 1.0000 & 1.0000 & 1.0000 \\
& $\mathrm{~A}_{3}$ & 0.8060 & 0.2983 & 0.2983 & 0.5522 & 0.8060 \\
\hline \multirow{2}{*}{ The modified } & $\mathrm{A}_{1}$ & 0.0000 & 0.0000 & 0.0000 & 0.0000 & 0.0000 \\
VIKOR method & $\mathrm{A}_{2}$ & 0.7645 & 0.9992 & 0.9992 & 0.8819 & 0.7645 \\
& $\mathrm{~A}_{3}$ & 1.0000 & 1.0000 & 1.0000 & 1.0000 & 1.0000 \\
\hline
\end{tabular}

On the basis of Table 3, it can be concluded that, based on the application of the modified VIKOR method, the same ranking of observed alternatives is obtained, as when applying statistical methods. However, using the traditional VIKOR method does not result in the same ranking of the observed alternatives that is obtained using the modified VIKOR method, and through the application of statistical method (Table 4).

Table 4. Ranking alternatives using statistical method

\begin{tabular}{lccc}
\hline Alternatives & $\mathrm{A}_{1}$ & $\mathrm{~A}_{2}$ & $\mathrm{~A}_{3}$ \\
\hline Mean value of guest expectations & 4.4413 & 4.4763 & 4.4615 \\
Mean value of guest expectations & 4.2500 & 3.9800 & 3.9600 \\
GAP between perception and expectation & -0.1913 & -0.4963 & -0.5025 \\
\hline
\end{tabular}

Based on the three rankings, it can be concluded that the best alternative is $A_{1}$ because the GAP between perception and expectation is smallest in the relation to the alternatives $A_{2}$ and $A_{3}$. It should be noted that 
hotels in mountain resorts offer a higher level of service quality, compared to hotels in cities $\left(\mathrm{A}_{2}\right)$ and spas $\left(\mathrm{A}_{3}\right)$. However, using the traditional VIKOR method leads to different ranking of alternatives in relation to the ranking, which is obtained using the modified VIKOR method. If we look at the ranking of alternatives as a result of applying the modified VIKOR method, the alternative $A_{2}$ is better than the alternative $A_{3}$. The same situation occurs if we look at the ranking of alternatives by applying the statistical method, i.e. the ranking of alternatives based on the difference between the mean values of guest perceptions and expectations. However, the application of the traditional VIKOR method results in the ranking that indicates that the alternative $A_{3}$ is better than the alternative $A_{2}$. The hypotheses $\mathrm{H} 1$ and $\mathrm{H} 2$ were not supported. Based on the above, it can be concluded that the modified VIKOR method can be successfully applied to rank the hotels based on the level of service quality, as the level of services provided is determined on the basis of respecting the hotel guest expectations and perceptions.

\section{CONCLUSION}

Service is a very important aspect of the hotel industry. Hotel service quality can be regarded as a composite measure of various attributes. It not only consists of tangible attributes but also intangible/ subjective attributes such as safety, quietness, which are difficult to measure accurately. Understanding what the guests expect represents a key phase in delivering high quality services. However, guests are the only ones who can define what quality hotel service are for them.

Service quality is a concept that has aroused considerable interest and debate in the research literature because of the difficulties in both defining it and measuring it. Bearing in mind that service quality is more difficult to be evaluated than commodity quality, in the paper, special attention was paid to the modification of the ENTROPY and the VIKOR methods. The results of the research indicate that the modified ENTROPY and the modified VIKOR methods result in the same ranking of the observed alternatives as well as the statistical methods while the traditional ENTROPY and the traditional VIKOR methods result in the different ranking of the observed alternatives compared to the statistical methods.

This study has four main empirical contributions to the literature in the field of marketing within tourism industry. The first refers to the results which indicate that guest expectations differ, depending on whether they visit the hotels which are located in the mountain, in the city, or in the spa. The second relates to the modification of the ENTROPY method, as a method that allows for the measurement of different hotel guest expectations. The third relates to the use of the modified VIKOR method, as a method for measuring service quality based on hotel guest expectations 
and perceptions. The fourth relates to the empirical measurement of service quality in hotels in other tourist destinations by using the modified ENTROPY and VIKOR methods with the aim if improving service quality.

The study has two main limitations. First, the study did not include all guests, but only those who were willing to participate in the survey. This fact can affect the deviation of the research results. Secondly, this study was conducted only during one season, i.e. from April $1^{\text {st }}$ to June $15^{\text {th }} 2017$. Guest expectations may vary depending on the time of year when they visit the hotel in the mountain or in the spa. Future research can focus on exploring the expectations and perceptions of the same guests who visit, for example, hotels in the mountains, but in different seasons.

\section{REFERENCES}

Bazzazi, A. A., Osanloo, M. \& Karimi, B. (2011). Deriving preference order of open pit mines equipment through MADM methods: application of modified VIKOR method. Expert Systems with Applications, 38, 2550-2556.

Buyukozkan, G. \& Gorener, A. (2015). Evaluation of product development partners using an integrated AHP-VIKOR model. Kybernetes, 44(2), 220-237.

Buyukozkan, G., Ruan D. \& Feyzioglu O. (2007). Evaluating e-learning web site quality in a fuzzy environment. International Journal of Intelligent Systems, 22(5), 567586.

Chen, W. J. (2013). Factors influencing internal service quality at international tourist hotels. International Journal of Hospitality Management, 35, 152-160. http://dx. doi.org/10.1016/j.ijhm.2013.06.004

Fu, H. P., Chu, K. K., Chao, P., Lee, H. H. \& Liao, Y. C. (2010). Using fuzzy AHP and VIKOR for benchmarking analysis in the hotel industry. The Service Industries Journal, 31(14), 2373-2389. http://dx.doi.org/10.1080/02642069.2010.503874

Getty, G. M. \& Thompson, K. N. (1994). The Relationship between Quality, Satisfaction and Recommending Behaviour in Lodging Decisions. Journal of Hospitality and Leisure Marketing, 2(3), 3-21.

Juwaheer, T. D. (2004). Exploring international tourists' perceptions of hotel operations by using a modified SERVQUAL approach - a case study of Mauritius. Managing Service Quality: An International Journal, 14(5), 350 - 364.

Kumar, R., Singh, H. \& Dureja, J. S. (2012). An approach to analyze logistic outsourcing problem in medium- scale organization by CFPR and VIKOR. Journal of Manufacturing Technology Management, 23(7), 885 - 898.

Liou, J. J., Tsai, C., Lin, R. \& Tzeng, G. (2011). A modified VIKOR multiple-criteria decision method for improving domestic airlines services quality. Journal of Air Transport Management, 17(2), 57-61. http://dx.doi.org/10.1016/j.jairtraman. 2010.03.004

Liua, R., Cui, L., Zeng, G., Wu, H., Wang, C., Yan, S. \& Yan, B. (2015). Applying the fuzzy SERVQUAL method to measure the service quality in certification \& inspection industry. Applied Soft Computing, 26, 508-512. http://dx.doi.org/ 10.1016/j.asoc.2014.10.014

Mohaghar, A., Fathi, M. R., Zarchi, M. H. \& Omidian, A. (2012). A combined VIKOR - Fuzzy AHP approach to marketing strategy selection. Business Management and Strategy, 3(1), 13-27. http://dx.doi.org/10.5296/bms.v3i1.957 
Mukherjee, A. \& Nath, P. (2005). An empirical assessment of comparative approaches to service quality measurement. Journal of Services Marketing, 19(3), 174 184. http://dx.doi.org/10.1108/08876040510596858

Opricovic, S. (1986). Višekriterijumska optimizacija [Multicriteria optimization]. Beograd: Naučna knjiga.

Opricovic, S. \& Tzeng, G. H. (2007). Extended VIKOR method in comparison with outranking methods. European Journal of Operational Research, 178(2), 514529. http://dx.doi.org/10.1016/j.ejor.2006.01.020

Parasuraman, A., Berry, L. L. \& Zeithaml, V. A. (1991). Perceived service quality as a customer-based performance measure: An empirical examination of organizational barriers using an extended service quality model. Human Resource Management, 30(3), 335-364.

Parasuraman, A., Berry, L. L. \& Zeithaml, V. A. (1993). More on improving service quality. Journal of Retailing, 69(1), 140-147.

Parasuraman, A., Berry, L. L. \& Zeithaml, V. A. (1990). Guidelines for conducting Service quality research. Marketing Research, 2(4), 34-44.

Parasuraman, A., Zeithaml, V. A \& Berry, L. L. (1994). Alternative scales for measuring service quality: a comparative assessment based on psychometric and diagnostic criteria. Journal of Retailing, 70(3), 201-230. http://dx.doi.org/10.1016/00224359(94)90033-7

Parasuraman, A., Zeithaml, V. \& Berry, L. (1988). SERVQUAL: A multiple-item scale for measuring consumer perceptions of service quality. Journal of Retailing, 64(1), 12-40.

Ramezaniyan, M., Kazemi, M., Jafari, H. \& Elahi, S. (2012). Application of integrated fuzzy VIKOR and AHP methodology to contractor ranking. Management Science Letters, 2(5), 1511-1526. http://dx.doi.org/10.5267/j.msl.2012.05.017

Rauch, D., Collins, M. D., Nale, R. D. \& Peter, B. B. (2015). Measuring service quality in mid-scale hotels. International Journal of Contemporary Hospitality Management, 27(1), 87 - 106. http://dx.doi.org/10.1108/IJCHM-06-2013-0254

Shannon, C. E. (1948). A mathematical theory of communication. The Bell System Technical Journal, 27(3), 379-423. http://dx.doi.org/10.1002/j.1538-7305.1948. tb01338.x

Shaverdi, M., Akbari, M. \& Tafti, S. F. (2011). Combining fuzzy MCDM with BSC approach in performance evaluation of Iranian private banking sector. Advances in Fuzzy Systems, 11, 1-12. http://dx.doi.org/10.1155/2011/148712

Shieh, J., Wu, H. \& Huang, K. (2010). A DEMATEL method in identifying key success factors of hospital service quality. Knowledge-Based Systems, 23(3), 277-282. http://dx.doi.org/10.1016/j.knosys.2010.01.013

Skalpe, O. \& Sandvik, K. (2002). The Economics of Quality in the Hotel Business. Tourism Economics, 8(4), 361-76. http://dx.doi.org/10.5367/00000000210129 8188

Tsai, H.Y., Chang, C. W. \& Lin, H. L. (2010). Fuzzy hierarchy sensitive with Delphi method to evaluate hospital organization performance. Expert Systems with Applications, 37(8), 5533-5541. http://dx.doi.org/10.1016/j.eswa.2010.02.099

Vinodh, S., Nagaraj, S. \& Girubha, J. (2014). Application of Fuzzy VIKOR for selection of rapid prototyping technologies in an agile environment. Rapid Prototyping Journal, 20(6), 523-532. http://dx.doi.org/10.1108/RPJ-07-2012-0060

Wattanakamolchai, S., Singal, M. \& Murrmann, S. (2014). Socially responsible consumers and the evaluation of service quality. Journal of Hospitality \& Tourism Research, 40(6), 715-738. http://dx.doi.org/10.1177/109634801452 5635 
Wang, C. \& Pang, C. (2011). Using VIKOR method for evaluating service quality of online auction under fuzzy environment. International Journal of Computer Science Engineering and Technology, 6(1), 307-314.

Wisniewski, M. (2001). Using SERVQUAL to assess customer satisfaction with public sector services. Managing Service Quality, 11(6), 380-388.

Wong, A. O. M., Dean, A. M. \& White, C. J. (1999). Analyzing service quality in the hospitality industry. Managing Service Quality, 2, 136- 143.

Wu, H. Y., Tzeng, G. H. \& Chen, Y. H. (2009). A fuzzy MCDM approach for evaluating banking performance based on balanced scorecard. Expert Systems with Applications, 36, 10135-10147. http://dx.doi.org/10.1016/j.eswa.2009. 01.005

Yucenur, G. N. \& Demirel, N. C. (2012). Group decision making process for insurance company selection problem with extended VIKOR method under fuzzy environment. Expert Systems with Applications, 39, 3702-3707. http://dx.doi.org/10.1016/j.eswa.2011.09.065

Zarei, A., Arab, M., Froushani, A. R., Rashidian, A. R. \& Tabatabaei, S. M. (2012). Service quality of private hospitals: The Iranian patients' perspective. BMC Health Service Research, 12(1), 31-37. http://dx.doi.org/10.1186/1472-6963-12-31

\title{
МОДИФИКОВАЊЕ ВИШЕКРИТЕРИЈУМСКИХ МЕТОДА У ЦИЉУ УНАПРЕЪЕЫА КВАЛИТЕТА УСЛУГА
}

\author{
Јелена Петровић \\ Универзитет у Нишу, Природно-математички факултет, Ниш, Србија а
}

\section{Резиме}

Услуге представљају веома значајан аспект хотелске индустрије. Квалитет хотелске услуге може се сматрати композитном мером различитих атрибута. Он се не састоји само од опипљивих атрибута већ и нематеријалних/субјективних атрибута као што су сигурност, тишина, који се тешко прецизно могу мерити. Разумевање онога шта гости очекују представља кључну фазу у оквиру испоруке висококвалитетних услуга. Међутим, гости су једини који могу дефинисати шта представља квалитет услуге за њих.

Квалитет услуге представља концепт који је изазвао значајан интерес и дебату у литератури због потешкоћа приликом њиховог дефинисања и мерења. Имајући у виду да је знатно компликованије извршити квантификацију квалитета услуга у односу на квалитет робе, у раду је посебна пажња посвећена модификацији ENTROPY методе и VIKOR методе.

Могу се издвојити четири главна емпиријска доприноса литератури у области менаџмента у оквиру туристичке индустрије. Први се односи на резултате који указују на то да се очекивања гостију разликују од тога да ли гости посећују хотеле који се налазе на планини, у граду или бањи. Други се односи на модификацију ENTROPY методе, као методе која омогућава мерење различитих очекивања гостију. Трећи се односи на употребу модификоване VIKOR методе, као методе за мерење квалитета услуга заснованог на очекивањима и перцепцији гостију. Четврти се односи на емпиријско мерење квалитета услуга у хотелима у другим туристичким дестинацијама користећи модификоване ENTROPY методе и VIKOR методе ради побољшања квалитета услуга. 
Истраживање има два основна ограничења. Прво, истраживање није обухватило све госте који су посетили хотеле, већ само оне који су били спремни да учествују у истраживању. Ова чињеница може утицати на одступање резултата истраживања. Друго, посматрано истраживање спроведено је само у оквиру једне сезоне, односно од 1. априла до 15. јуна 2017. године. Очекивања госта могу се разликовати у зависности од времена у години када посете хотел на планини или у бањи. Будућа истраживања могу се усредсредити на истраживање очекивања и перцепција истих гостију, који посећују, на пример, хотеле на планинама, али током различитих годишњих доба. 